\title{
ION CLUSTERS AND THE VENUS ULTRAVIOLET HAZE LAYER
}

\section{A. C. AIKIN}

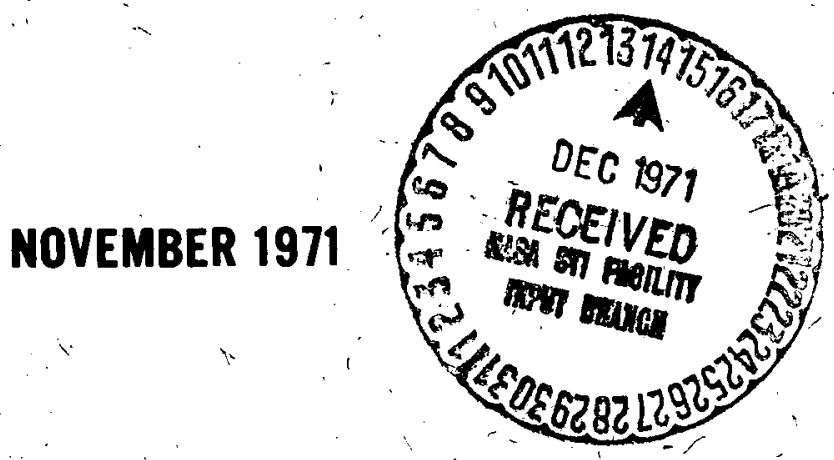

N72-12842

Unclas

09753
(NASA-TH-X-65773) ION CLUSTERS AND THE
VENUS ULTRAVIOLET HAZE LAYER A.C. Aikin
(NASA) NOV. 1971 B p

$\mathrm{G} 3 / 30$

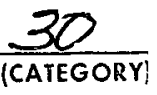

Reproduced by

NATIONAL TECHNICAL INFORMATION SERVICE U S Department of Commerce 
ION CLUSTERS AND THE VENUS ULTRAVIOLET HAZE LAYER

by

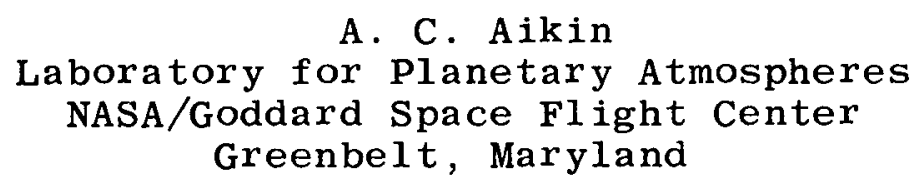

The daytime ionosphere of Venus is observed between 100 and $500 \mathrm{~km}$ altitude with a peak electron concentration of $5 \times 10^{5} \mathrm{~cm}^{-3}$ at $140 \mathrm{~km} .{ }^{1}$ Below $200 \mathrm{~km} \mathrm{CO}_{2}{ }^{+}$is thought to be the principal ion ${ }^{2}, 3$ unless oxygen is present. We suggest that at altitudes less than $130 \mathrm{~km}$ the ion $\mathrm{CO}_{2}{ }^{+} \cdot \mathrm{CO}_{2}$ is an important ionic constituent of the venus ionosphere. Below $100 \mathrm{~km}$ ion clustering processes combine with the low temperature at the mesopause to form coagulates giving rise to the ultraviolet haze layer which has frequently been observed.

For clustering of neutrals to ions Keller and Beyer 4 have shown the dependence of clustering rate on the polarizability of the neutral molecule and the mass of the ion. A rate of $k_{1}=5 \times 10^{-30} \mathrm{~cm}^{6} \mathrm{sec}^{-1}$ and $\mathrm{k}_{-1}=5 \times 10^{-14} \mathrm{~cm}^{3} \mathrm{sec}^{-1}$ would be predicted for the reactions

$$
\mathrm{CO}_{2}^{+}+\mathrm{CO}_{2}+\mathrm{CO}_{2} \underset{\mathrm{k}-1}{\stackrel{\mathrm{k}_{1}}{\rightleftarrows}} \mathrm{CO}_{2}^{+} \cdot \mathrm{CO}_{2}+\mathrm{CO}_{2}
$$

The forward reaction has been observed in the laboratory 
with a rate of $3 \times 10^{-28} \mathrm{~cm}^{6} \mathrm{sec}^{-1}$ at $1 \mathrm{ev}^{5}$. In addition dissociative ion-electron recombination is operative in the ionosphere

$$
\mathrm{CO}_{2}^{+} \cdot \mathrm{CO}_{2}+\mathrm{e} \rightarrow \mathrm{CO}_{2}+\mathrm{CO}_{2}
$$

Based on a measured rate of $2.3 \times 10^{-6} \mathrm{~cm}^{3} \mathrm{sec}^{-1}$ for $\mathrm{O}_{4}^{+}-$ electron recombination ${ }^{6}$ a rate of $\alpha_{D}=2.3 \times 10^{-6}\left(\frac{300}{T}\right)$ will be assumed for (2) where $T$ is the temperature. The ratio $\mathrm{CO}_{2}^{+} \cdot \mathrm{CO}_{2} / \mathrm{CO}_{2}^{+}$is

$$
\frac{\left[\mathrm{CO}_{2}{ }^{+} \cdot \mathrm{CO}_{2}\right]}{\left[\mathrm{CO}_{2}{ }^{+}\right]}=\frac{\mathrm{k}_{1}\left[\mathrm{CO}_{2}\right]^{2}}{\mathrm{k}_{-1}\left[\mathrm{CO}_{2}\right]+\alpha_{D} \mathrm{~N}_{\mathrm{e}}}
$$

and plotted as a function of altitude in Figure 1. The atmospheric model chosen is the Goddard Space Flight Center model ${ }^{7}$. At altitudes below $90 \mathrm{~km}$, where cosmic rays are the dominant source of ionization the ion ratio

$$
\frac{\left[\mathrm{Co}_{2}^{+} \cdot \mathrm{CO}_{2}\right]}{\left[\mathrm{Co}_{2}^{+}\right]}
$$

is greater than one. Above $100 \mathrm{~km}$ the ratio is less than unity.

If $\mathrm{N}_{2}$ and $\mathrm{O}_{2}$ are present in the Venus atmosphere, then the processes

$$
\mathrm{CO}_{2}^{+}+\mathrm{N}_{2}+\mathrm{CO}_{2} \rightarrow \mathrm{CO}_{2}^{+} \cdot \mathrm{N}_{2}+\mathrm{CO}_{2}
$$


and

$$
\mathrm{CO}_{2}^{+}+\mathrm{O}_{2}+\mathrm{CO}_{2} \rightarrow \mathrm{CO}_{2}^{+} \cdot \mathrm{O}_{2}+\mathrm{CO}_{2}
$$

as well as $\mathrm{CO}_{2}{ }^{+}+\mathrm{O}_{2} \rightarrow \mathrm{O}_{2}{ }^{+}+\mathrm{CO}_{2}$ will cause loss of $\mathrm{CO}_{2}{ }^{+}$. The formation and loss processes of $\mathrm{O}_{2}{ }^{+} \cdot \mathrm{CO}_{2}$ have been discussed previously for the case of the Martian atmosphere ${ }^{8}$.

The presence of $\mathrm{O}_{2}$ will lead to the formation of negative ions ${ }^{9}$ which will modity (3) by the addition of a loss term for $\mathrm{CO}_{2}^{+} \cdot \mathrm{CO}_{2}$ involving ion-ion recombination.

In the event that water vapor is present above the cloud tops reaction occur such as

$$
\begin{array}{r}
\mathrm{CO}_{2}^{+} \cdot \mathrm{CO}_{2}+\mathrm{H}_{2} \mathrm{O}+\mathrm{CO}_{2} \rightarrow \mathrm{CO}_{2}^{+} \cdot \mathrm{H}_{2} \mathrm{O}+\mathrm{CO}_{2} \\
\mathrm{CO}_{2}^{+} \cdot \mathrm{H}_{2} \mathrm{O}+\mathrm{H}_{2} \mathrm{O} \rightarrow \mathrm{H}_{3} \mathrm{O}^{+}+\mathrm{CO}_{2}+\mathrm{OH}
\end{array}
$$

Coffey ${ }^{10}$ has shown that $\mathrm{H}_{3} \mathrm{O}^{+} \cdot\left(\mathrm{H}_{2} \mathrm{O}\right)_{\mathrm{n}}$ can react with $\mathrm{NH}_{4}$ and $\mathrm{HCl}$ to form $\mathrm{NH}_{4} \mathrm{Cl} \cdot\left(\mathrm{H}_{2} \mathrm{O}\right)_{n}$ by the chain

$$
\begin{aligned}
& \mathrm{H}_{3} \mathrm{O}^{+} \cdot\left(\mathrm{H}_{2} \mathrm{O}\right)_{\mathrm{n}}+\mathrm{NH}_{4} \rightarrow \mathrm{NH}_{4}^{+} \cdot\left(\mathrm{H}_{2} \mathrm{O}\right)_{\mathrm{n}}+\mathrm{H}_{3} \mathrm{O} \\
& \mathrm{NH}_{4}{ }^{+} \cdot\left(\mathrm{H}_{2} \mathrm{O}\right)_{\mathrm{n}}+\mathrm{HCl} \rightarrow \mathrm{NH}_{4} \mathrm{Cl}\left(\mathrm{H}_{2} \mathrm{O}\right)_{\mathrm{m}}+\mathrm{H}_{3}{ }^{+} \mathrm{O}\left(\mathrm{H}_{2} \mathrm{O}\right)(\mathrm{n}-\mathrm{m})
\end{aligned}
$$

It has further been observed that the compound $\mathrm{NH}_{4} \mathrm{Cl}\left(\mathrm{H}_{2} \mathrm{O}\right)_{\mathrm{m}}$ coagulates easily to form micron sized particles.

Kuiper ${ }^{11}$ has suggested that the venus ultraviolet haze layer is composed of $0.1 \mu$ sized particles of $\mathrm{NH}_{4} \mathrm{Cl}$. The location of this layer at $90 \mathrm{~km}$ is illustrated in 
Figure 2 which shows the temperature distribution for the atmospheric model employed. Also indicated are the levels of the yellow haze layer and the ratio of cluster ions relative to $\mathrm{CO}_{2}^{+}$.

An alternate source of coagulates may be the ion $\mathrm{CO}_{2}{ }^{+} \cdot \mathrm{H}_{2} \mathrm{O}$, which can attach additional water molecules as well as other neutral molecules. The complexes $\mathrm{CO}_{2}^{+} \cdot\left(\mathrm{H}_{2} \mathrm{O}\right) \cdot \mathrm{XY}$ can form as has been observed with $\mathrm{NO}^{+}, \mathrm{H}_{2} \mathrm{O}, \mathrm{SO}_{2}$ systems 12 . The resulting complex will further react to eliminate the ion and form coagulatable compounds. Laboratory studies at Venus atmosphere conditions will define more clearly the importance of ion clustering processes in the formation of the Venus ultraviolet haze layer. 


\section{REFERENCES}

1. Fjeldbo, G. and V.R. Eshleman, Radio Science, $\underline{4}, 879$, (1969) .

2. McElroy, M.B., J. Geophys. Res., 74, 29 (1969).

3. Herman, J.R., R.E. Hartle and S.J. Bauer, Planet. Space Sci. , 19, 443 (1971).

4. Beyer, R.A. and G.E. Keller, Trans. Am. Geophys. Union, 52,303 (1970).

5. Paulson, J.F., F. Dale and R.L. Mosher, Nature, 204, 377 (1964).

6. Kasner, W.H. and M.A. Biondi, Phys. Rev., 174, 139 (1968).

7. Ainsworth, J.E., Goddard Space Flight Center Document, $\mathrm{X}-625-70-203(1970)$.

8. Whitten, R.C., I.G. Poppoff and J.S. Sims, Planet. Space Sci., 19,243 (1971).

9. Aikin, A.C., Icarus, $\underline{9}, 487$ (1968).

10. Coffey, P.C., Bu11. Am. Phys. Soc., 16, (1971).

11. Kuiper, G., Comm. of the Lunar and Planet. Lab. Comm. NOS 100-104, 6, 229 University of Arizona 1968-1969.

12. Castleman, A.W., I.N. Tang and H.R. Munkelwitz, Science, $\underline{173}, 1025$ (1971). 


\section{F IGURE CAPTIONS}

Figure 1 - The ratio $\mathrm{CO}_{2}{ }^{+} \cdot \mathrm{CO}_{2} / \mathrm{CO}_{2}{ }^{+}$as a function of altitude. Figure 2 - Altitude level of the Venus yellow cloud layer and untraviolet haze layer in relation to the temperature distribution of the atmosphere and the ratio of $\mathrm{CO}_{2}{ }^{+} \cdot \mathrm{CO}_{2}$ to $\mathrm{CO}_{2}{ }^{+}$. 


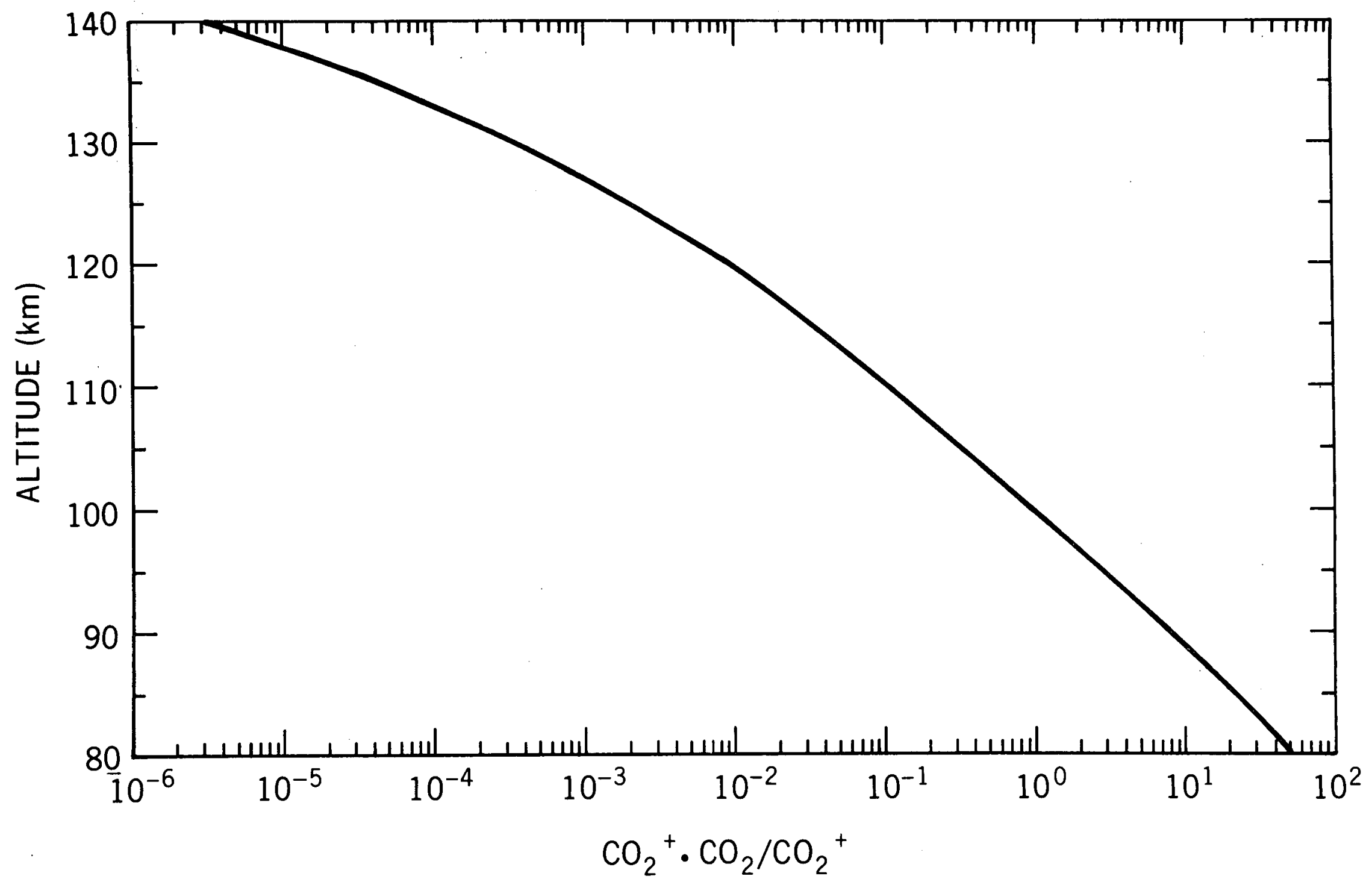

Figure 1 


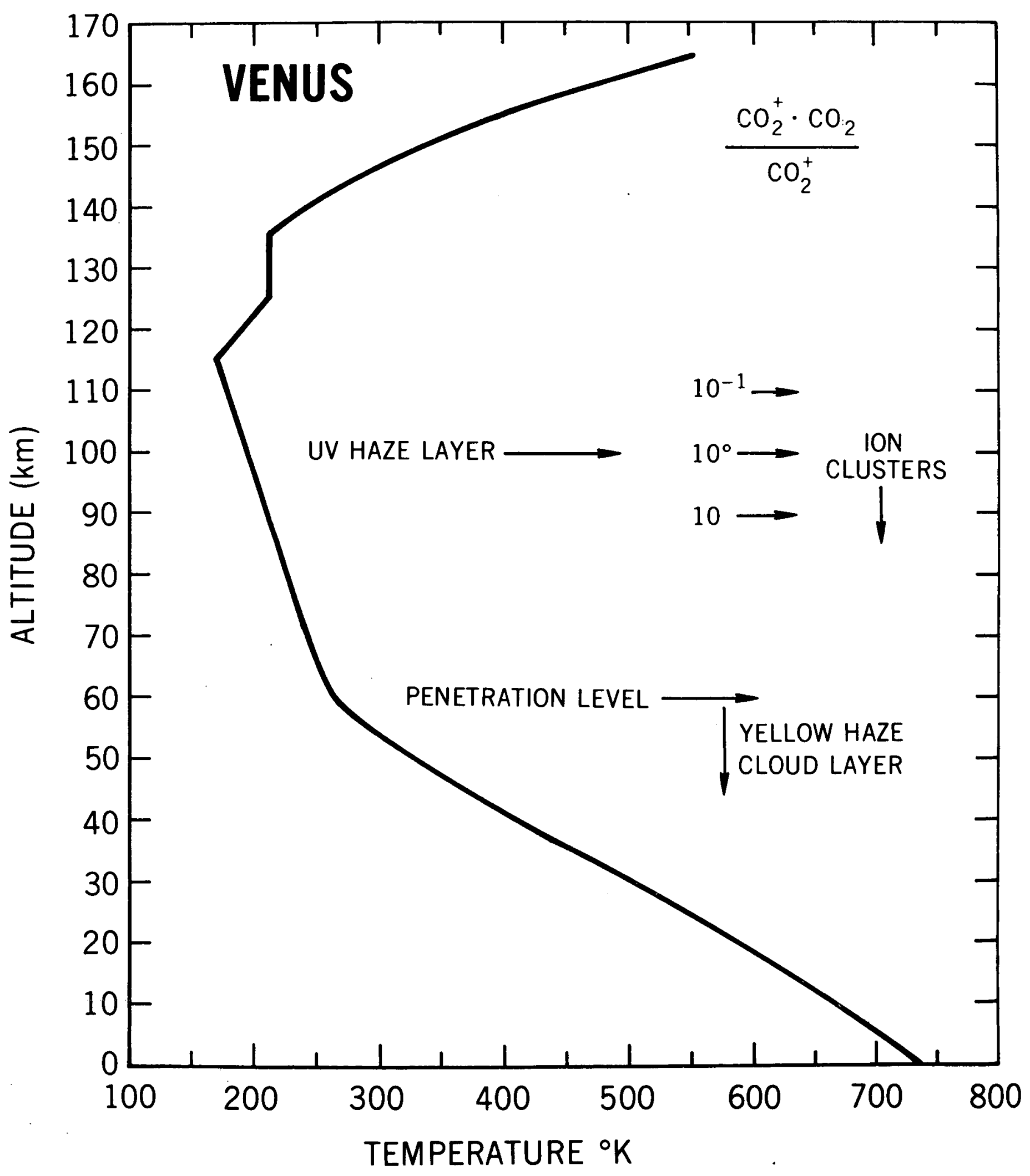

Figure 2 